DOI https://doi.org/10.30525/978-9934-26-046-9-57

\title{
НАУКОВО-ТЕХНІЧНА ДІЯЛЬНІСТЬ У РЕАЛІЯХ СЬОГОДЕННЯ: ДОСЯГНЕННЯ, АКТУАЛЬНІ ПИТАННЯ ТА ПЕРСПЕКТИВИ
}

\author{
Кривулькін I. М. \\ кандидат фізико-математичних наук, \\ директор
}

Науково-дослідний, проектно-конструкторський та технологічний інститут мікрографії

\section{Гребцова I. A.}

заступник завідувача відділу

Науково-дослідний, проектно-конструкторський та технологічний інститут мікрографії

м. Харків, Україна

Напрями досліджень, які охоплюють питання технічного спрямування, різні та мають специфіку за галузями. Діяльність та звітність бюджетних наукових установ регламентовано низкою нормативноправових актів [1]-[2]. Практичне застосування набутих доробок та втілення у виробничу діяльність - найголовніше завдання, визначене вимогами економічної доцільності виконання науково-технічних робіт.

Унікальною профільною установою є Науково-дослідний, проектно-конструкторський та технологічний інститут мікрографії (НДІ мікрографіï) - єдина наукова установа в Україні, що здійснює прикладні дослідження і займається вирішенням актуальних науковотехнічних завдань державної системи страхового фонду документації (далі - СФД).

Важливість цієї системи для держави, враховуючи забезпечення інформаційної складової національної безпеки, визначена і регламентована комплексом законодавчих та нормативно-правових актів, зокрема Законом України [3], та підтверджена на практиці. На сьогодні СФД - єдине джерело інформації в Україні про культурні цінності, які залишились на непідконтрольних Україні територіях АР Крим, м. Севастополя, Донецької та Луганської областей. На базах зберігання СФД України відновлюються дані з документів СФД, що дозволить 
Мінкультури створити відповідний реєстр та відстоювати права держави у міжнародних судах. Крім того, на цей час проводиться організація робіт з виготовлення копій документів СФД на низку виробів військового призначення з документації, оригінали якої втрачені в результаті військового конфлікту для подальшої розробки на їх основі новітніх зразків озброєння. Документ страхового фонду (документації) - документ, який знаходиться на державному обліку у СФД України і необхідний для поставлення на виробництво, експлуатацію та ремонт продукції оборонного, мобілізаційного і господарського призначення, для проведення будівельних (відбудовчих), аварійно-рятувальних та аварійно-відновлювальних робіт під час ліквідування надзвичайних ситуацій та в особливий період, а також для збереження культурної спадщини, на випадок утрати або псування оригіналу документа [3].

Стабільне функціювання повного циклу комплексу виробничих потужностей спеціальних установ СФД України забезпечується виконанням досліджень у широкому спектрі напрямків, починаючи з розроблення технологічної, проєктної, конструкторської, нормативної та програмної документації до її апробації та впровадження.

Ефективними для спільноти можуть бути запропоновані НДІ мікрографії технології збереження інформації за допомогою мікрофільмування (створення фотокопій документів, рукописів, мап, креслень тощо, виконаних зі значним зменшенням на фотоплівці та надійне зберігання з наступним відтворенням в паперовому вигляді), а саме: технологія створення зображень у цифровому вигляді, що містять інформацію про культурні цінності, для формування, ведення і використання СФД України (реєстраційний номер в Державному реєстрі технологій 0620U000125); автоматизовані цифрові технології для технологічних операцій контролю та підготовки до мікрофільмування цифрових зображень документів СФД України (0620U000122); технологія кодування та декодування цифрової інформації у вигляді бітових потоків для виготовлення мікрофільмів та відтворення з них копій (0620U000135) та інші [4].

Актуальними проблемами мікрофільмування та збереженням важливої для безпеки кожної держави інформації опікуються провідні країни світу.

Задля набуття досвіду, переймання та адаптування технічних аспектів технологічного процесу мікрофільмування до можливостей в Україні НДІ мікрографії активно провадить міжнародне співробітництво. Технічний комітет стандартизації (ТК 40), функції ведення 
секретаріату якого здійснює інститут, $є$ постійним членом міжнародних комітетів ISO/TC 42 «Фотографія», ISO/TC 46 «Інформація і документація», ISO/TC 171 «Управління документообігом» та ISO/TC 292 «Безпека».

Однак, актуальними проблемними питаннями залишаються на часі:

- технологічні загрози (припинення випуску плівки для мікрофільмування, повне припинення виробництва фунгіцидів для обробки мікрофільмів СФД від грибків за розробленою НДІ мікрографії технологією);

- соціальні загрози (зниження престижності наукової роботи, низький рівень підтримки науковців, відсутність заохочення передавання досвіду робіт);

- фінансові загрози (недостатність фінансування досліджень, яке щорічно катастрофічно знижується, зокрема відсутність можливості оновлення експериментальної бази, відсутність матеріальнотехнічного забезпечення).

Перспективи розвитку та розширення можливостей насправді існують - це і перехід на збереження інформації з використанням СОМсистем (перспективний розвиток гібридних технологій для модернізації традиційного процесу), і застосування везикулярної плівки, і можливість виготовлення лише на цифровому устаткованні документів СФД з урахуванням новітніх галузевих науково-технічних досягнень тощо.

Таким чином, у зв'язку із розвитком цифровізації та інформатизації суспільства й економіки, гармонізації законодавчої та нормативної бази України з європейською системою технічного регулювання, удосконаленням технологій розроблення документації, що надається на мікрофільмування до державної системи СФД, виокремлено ряд актуальних напрямів досліджень, що у найближчій перспективі сприятимуть вдосконаленню чинного нормативно-методичного та технологічного комплексу забезпечення формування, ведення та використання СФД України на підставі прикладних досліджень та науковотехнічних (експериментальних) розробок.

\section{Література:}

1. Про наукову та науково-технічну діяльність: Закон України від 26 листопада 2015 р. № 848-VIII / Верховна Рада України. URL: https://zakon.rada.gov.ua/laws/show/848-19\#Text (дата звернення: 06.03.2021). 
2. Порядок формування тематики наукових досліджень і науковотехнічних (експериментальних) розробок, що фінансуються за рахунок коштів державного бюджету: затв. постановою Кабінету Міністрів України від 11 січня 2018 р. № 13. URL: https://zakon.rada.gov.ua/ laws/show/13-2018-п\#Tехt (дата звернення: 06.03.2021).

3. Про страховий фонд документації України: Закон України від 23 березня 2001 р. № 2332-III / Верховна Рада України. URL: https://zakon.rada.gov.ua/laws/show/2332-14\#Tех (дата звернення: 06.03.2021).

4. Державний реєстр технологій. URL: http://rkt.ukrintei.ua/search

DOI https://doi.org/10.30525/978-9934-26-046-9-58

\title{
ОГЛЯД СУЧАСНОЇ ТЕХНІКИ ДЛЯ МЕХАНІЗАЦЇ̈ ТЕХНОЛОГІЧНИХ ПРОЦЕСІВ У САДІВНИЦТВІ
}

\author{
Кутковецька Т. О. \\ кандидат економічних наук, доиент, \\ дочент кафедри агроінженерії \\ Уманський національний університет садівництва \\ Дідур В. В. \\ кандидат технічних наук, \\ дочент кафедри агроінженерії \\ Уманський національний університет садівництва \\ м. Умань, Черкаська область, Україна
}

На сьогодні використання сучасної сільськогосподарської техніки в будь-якій галузі є невід'ємною складовою ведення господарства, що в свою чергу дає можливість як найменших витрат на виробництво 3 отриманням високого прибутку в майбутньому. Галузь садівництва $\epsilon$ трудомісткою галуззю, тому без використання засобів механізації технологічних процесів у садівництві неможливе ведення його на сучасному рівні.

Як при вирощуванні сільськогосподарських культур, так і при веденні садівництва виконуються наступні роботи: обробіток грунту, догляд за насадженнями та збір урожаю. Для наведеного виду 